\title{
Study of influence of a model guidance about the laboratory tests and disease in knowledge and self-management of patients with type 2 DM
}

Maria de Lourdes Baêta Zille

From 20th Brazilian Diabetes Society Congress

Porto Alegre, Brazil. 11-18 November 2015

\section{Background}

Diabetes mellitus (DM) has been considered a growing worldwide epidemic, with global distribution, more prevalent in developing countries. This disease causes a reduction in the quality of life of people who have it, and has brought about the increase of problems for public health systems, with extremely high social costs, especially when diagnosed late. In turn, the possibility of increasing the knowledge of the disease, in conjunction with individual behavior changes by persons with T2D, is a strategy to be considered in order for these individuals to be able to control glycemic levels more easily.

\section{Objective}

Bearing this in mind, this study has the objective of evaluating the efficacy of the methodology of an educational program based on improving self-knowledge of diabetes, while also analyzing lab results, and treating the disease.

\section{Materials and methods}

This study was done with 76 patients with diabetes (68.4\% women and $31.6 \%$ men) registered in 12 health clinics of the central-south sanitary district of the municipal health department of Belo Horizonte. The analysis of the patients' level of knowledge before and after the implementation of the program was based on questionnaires given to patients before and after intervention.

\section{Results}

Of exams done before and after the intervention, the following averages were obtained: Glycemia before the

Correspondence: malutaf@terra.com.br

SMSA/Prefeitura Municipal de Belo Horizonte, Belo Horizonte, Brazil intervention: $161,4 \mathrm{mg} / \mathrm{dL}$ and after the interventons: $136,4 \mathrm{mg} / \mathrm{dL}$, Total Cholesterol before the intervention: $189,4 \mathrm{mg} / \mathrm{dL}$ and after: 175,5 , Triglyceride before: 160.6 $\mathrm{mg} / \mathrm{dL}$ and after: $135,6 \mathrm{mg} / \mathrm{dL}, \mathrm{HbA} 1 \mathrm{C}$ before the intervention: $8.6 \%$ and $\mathrm{HbA1C}$ after the intervention: $7.8 \%$.

\section{Conclusion}

Notably, the improvement in the lab Results thus suggests the efficacy, in the context of this research, of the methodology utilized to better patients' self-knowledge of diabetes.

Published: 11 November 2015

doi:10.1186/1758-5996-7-S1-A164

Cite this article as: de Lourdes Baêta Zille: Study of influence of a model guidance about the laboratory tests and disease in knowledge and selfmanagement of patients with type 2 DM. Diabetology \& Metabolic Syndrome 2015 7(Suppl 1):A164.

Submit your next manuscript to BioMed Central and take full advantage of:

- Convenient online submission

- Thorough peer review

- No space constraints or color figure charges

- Immediate publication on acceptance

- Inclusion in PubMed, CAS, Scopus and Google Scholar

- Research which is freely available for redistribution 


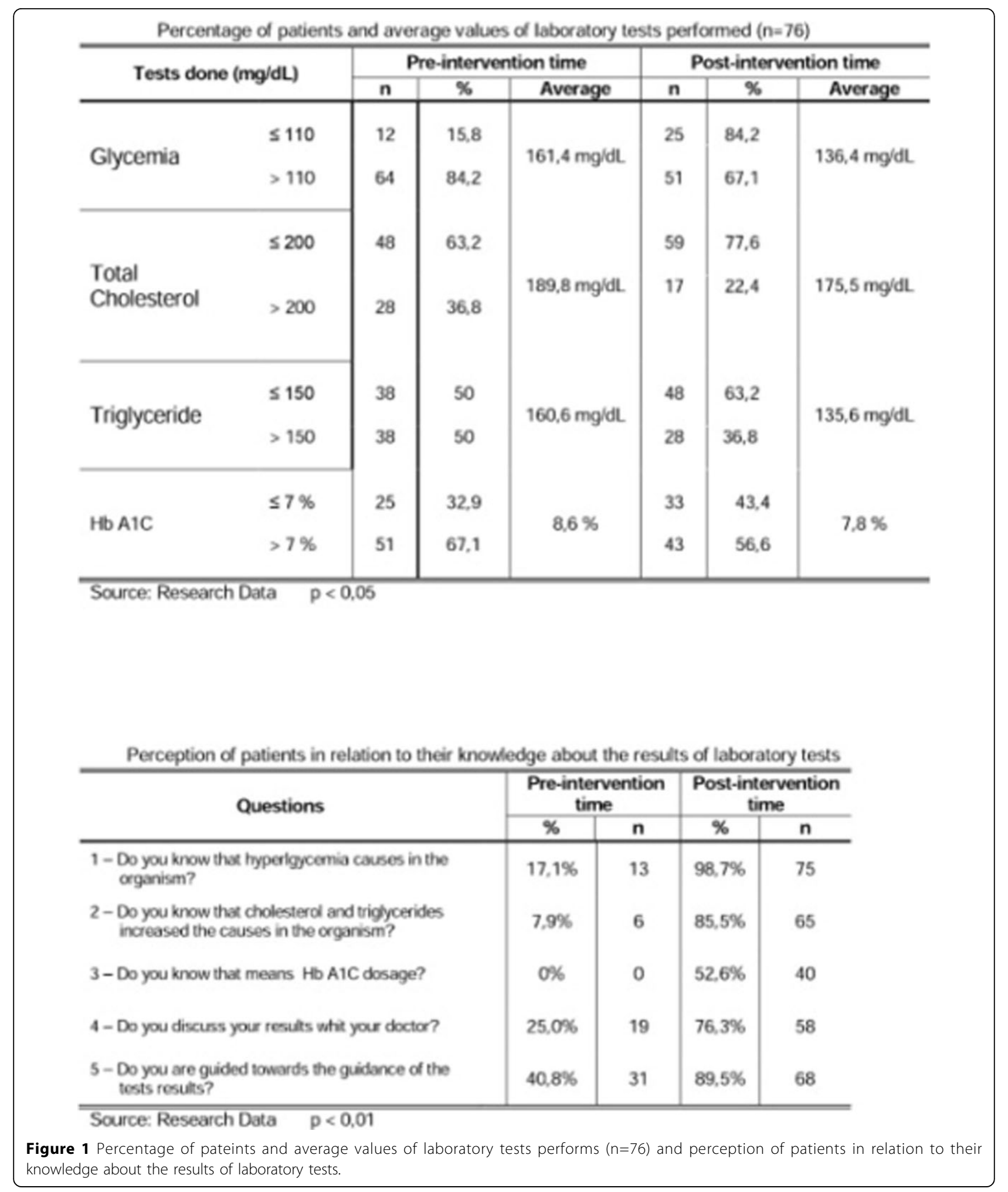

